\begin{tabular}{ll|l} 
Case Reports in & \multicolumn{2}{c}{ Case Rep Gastroenterol 2013;7:369-375 } \\
\cline { 2 - 3 } Gastroenterology & $\begin{array}{l}\text { DOI: 10.1159/000355163 } \\
\text { Published onlne: September 5, 2013 }\end{array}$ & $\begin{array}{l}\text { ○ 2013 S. Karger AG, Basel } \\
\text { www.karger.com/crg }\end{array}$ \\
\hline & $\begin{array}{l}\text { This is an Open Access article licensed under the terms of the Creative Commons } \\
\text { Attribution-NonCommercial 3.0 Unported license (CC BY-NC) (www.karger.com/OA- } \\
\text { license), applicable to the online version of the article only. Distribution permitted for non- } \\
\text { commercial purposes only. }\end{array}$
\end{tabular}

\title{
Incidental Finding of Isolated Colonic Neurofibroma
}

\author{
Haritha Chelimilla ${ }^{a} \quad$ Chaitanya K. Chandrala ${ }^{a}$ Masooma Niazi ${ }^{b}$ \\ Kavitha Kumbum ${ }^{\text {a }}$ \\ Divisions of ${ }^{a}$ Gastroenterology and ${ }^{b}$ Pathology, Department of Medicine, Bronx Lebanon \\ Hospital Center, Affiliated with Albert Einstein College of Medicine, Bronx, N.Y., USA
}

\section{Key Words}

Neurofibromatosis $\cdot$ Intestinal $\cdot$ Colonic polyps $\cdot$ Neurofibroma

\begin{abstract}
Neurofibromatosis is a genetic disorder manifested by characteristic cutaneous lesions called neurofibromas. There are two distinct neurocutaneous syndromes named neurofibromatosis type 1 (also called von Recklinghausen disease or NF1) and neurofibromatosis type 2 (NF2). NF1 is by far the most common presentation and is caused by an autosomal dominant mutation in the NF1 gene mapped to chromosome 17q11.2. The literature shows that gastrointestinal involvement is noted in systemic neurofibromatosis in up to $25 \%$ of patients, but isolated intestinal neurofibromatosis is a very rare manifestation. We herein present the case of a 70-year-old woman who was diagnosed with an isolated colonic neurofibroma without any systemic signs of neurofibromatosis; only a few case reports of this condition have been published to date.

(c) 2013 S. Karger AG, Basel
\end{abstract}

\section{Introduction}

Isolated intestinal neurofibromas involving the gastrointestinal mucosa are a very rare presentation and only 10 case reports have been published to date in the English literature. The clinical presentation of these patients has been varied, from completely asymptomatic to massive lower gastrointestinal bleeding requiring intervention. The diagnosis is always made at histopathological examination after either surgical resection of the involved bowel or colonoscopic removal of the polyps. After removal of the neurofibromas, most patients do not develop any immediate systemic or local recurrent gastrointestinal neurofibromas in the short term, however there are no studies published with information on long-term follow- 
Chelimilla et al.: Incidental Finding of Isolated Colonic Neurofibroma

up. Considering the tumorigenesis of neurofibromas, it is warranted that these patients be closely followed up.

\section{Case Report}

A 70-year-old woman was referred to our gastroenterology clinic for colon cancer screening. She denied abdominal pain, nausea, vomiting, heartburn, irregular bowel habits or hematochezia. She had undergone colonoscopy 10 years prior at an outside facility which according to her had been unremarkable. Her past medical history included migraine, hypertension, coronary artery disease and osteopenia. Her home medications included aspirin, hydrochlorothiazide, metoprolol, simvastatin, calcium, vitamin D and alendronate. Her family history was significant for stomach cancer in a sister, lung cancer in a brother and thyroid cancer in a daughter. She denied any family history of neurological tumors and cutaneous neurofibromas. She had a 40-pack-year smoking history, which she quit for 12 years. Physical examination revealed an overweight woman with a body mass index of 29. Her abdomen was soft with no tenderness or palpable masses. She did not have any skin lesions or pigmented/hypopigmented spots. Abdominal and neurological exams were within normal limits. Laboratory data revealed a hemoglobin level of $13.9 \mathrm{~g} / \mathrm{dl}$, a white blood cell count of $8,100 / \mu \mathrm{l}$, a platelet count of $251,000 / \mu \mathrm{l}$ and a serum creatinine of $0.9 \mathrm{mg} / \mathrm{dl}$. Basic metabolic panel, liver function tests and coagulation profile were within normal limits. Hepatitis serology was negative.

As part of routine screening, colonoscopy was performed up to the cecum. Findings included a $20-\mathrm{mm}$ pedunculated polyp with a stalk measuring $0.6 \mathrm{~cm}$ in length and $0.4 \mathrm{~cm}$ in diameter in the ascending colon (fig. 1), and an 8-mm polyp in the transverse colon removed with polypectomy and a 3-mm polyp in the ascending colon removed with biopsy forceps. Other findings were diverticulosis of the entire colon and internal hemorrhoids. The 8-mm transverse colon polyp revealed tubular adenoma on histopathology, and the 3-mm ascending colon polyp revealed colonic mucosa. Histologically, the pedunculated ascending colon polyp revealed bland spindle cell proliferation in the submucosa (fig. 2, fig. 3). Immunohistochemical stains showed that the tumor cells were immunoreactive to S100 protein (fig. 4) and were non-reactive to CD117, SMA and desmin antibodies. These findings were consistent with a diagnosis of colonic submucosal neurofibroma. The patient continued to be followed up in our outpatient clinic. She remains asymptomatic without any systemic signs of neurofibromatosis even after 9 months of follow-up.

\section{Discussion}

Neurofibromas are benign neoplasms consisting of neural and connective tissue components like Schwann and perineural cells and myofibroblasts. Neurofibromas can be confirmed with S100 protein immunostaining [1]. The differential diagnosis of neural lesions of the colon besides neurofibromas includes ganglioneuromas, schwannomas, perineuriomas and granular cell tumors [2]. Neurofibromas can be solitary, multiple or plexiform. They are usually multiple at presentation and are part of a hereditary disorder with two clinical forms: neurofibromatosis type 1 (von Recklinghausen neurofibromatosis or peripheral neurofibromatosis; NF1) and neurofibromatosis type 2 (central neurofibromatosis or bilateral acoustic neurofibromatosis; NF2). These disease entities have variable clinical expressions with manifestations involving the skin, nervous system, eyes, bones, gastrointestinal tract 
Chelimilla et al.: Incidental Finding of Isolated Colonic Neurofibroma

and other body parts. Gastrointestinal tract involvement has been reported in 25\% of patients with NF1, with most cases involving the stomach or small bowel [3].

The pathological forms of gastrointestinal involvement consist of ganglioneuromatosis characterized by hyperplasia and hypertrophy of the nerve plexuses and ganglionic cells in the mucosa, and/or neurofibromatosis characterized by hyperplasia of neuronal cells in the submucosa, muscularis propria or even from the serosa. Sometimes it is also associated with gastrointestinal stromal tumors with different degrees of neuronal and smooth muscle differentiation and carcinoid tumors of the periampullary region which may be associated with pheochromocytoma [4-6].

Intestinal neurofibromas are generally submucosal but may extend to the serosa. Dense growths known as plexiform neurofibromatosis of the mesentery or retroperitoneal space may lead to arterial compression or nerve injury. Although there is no specific symptom associated with gastrointestinal neurofibromatosis, clinical manifestations include abdominal pain, constipation, anemia, melena and an abdominal mass. Serious complications that have been reported include intestinal or biliary obstruction, ischemic bowel, perforation, intussusception and megacolon.

Solitary neurofibromas of the colon are extremely rare and usually occur in association with NF1. Even more rare are isolated neurofibromas without any other systemic signs of neurofibromatosis. We did an extensive literature review of published articles in PubMed on intestinal neurofibromas and found only 10 case reports of isolated colonic neurofibromas. In table 1 we present the data of isolated gastrointestinal neurofibromas in adults without any systemic signs of von Recklinghausen disease. Age at diagnosis, gender and location of the neurofibromas are also presented. Interestingly, most of these cases, including our case, were females. The age at diagnosis ranged from 45 to 70 years and there was a slight predilection to rectum involvement. The majority of cases were identified during routine colonoscopy. Our patient is another example of the same. Clinical symptomatology may depend on the macroscopic appearance of the lesion and its location in the gastrointestinal tract. Few patients presented with iron deficiency anemia, while some had gross lower gastrointestinal bleeding and others had symptoms of intestinal obstruction. Occasionally, isolated intestinal neurofibromas may be the initial sign of NF1 in patients without any other clinical manifestations of the disease.

Solitary neurofibromas have also been reported in other parts of the gastrointestinal tract, such as the mesentery [7], the ileum [8], the anal canal [9], the esophagus [10], the soft palate [11], the gallbladder [12] and the common bile duct [13], to mention a few. The clinical significance of isolated neurofibromas has not been well studied. The natural history of these lesions is typically benign, but malignant transformation has been reported, particularly in association with NF1 and in larger, plexiform lesions [14]. With such low incidence and very few cases reported, long-term follow-up goals and screening are still undetermined at this time, but close clinical follow-up of these patients is important to exclude neurofibromatosis and its associated risk of malignant transformation.

\section{References}

-1 Korf BR: Neurofibromatosis. Handb Clin Neurol 2013;111:333-340.

-2 Gibson JA, Hornick JL: Mucosal Schwann cell 'hamartoma': clinicopathologic study of 26 neural colorectal polyps distinct from neurofibromas and mucosal neuromas. Am J Surg Pathol 2009;33:781-787.

-3 Hochberg FH, Dasilva AB, Galdabini J, Richardson EP Jr: Gastrointestinal involvement in von Recklinghausen's neurofibromatosis. Neurology 1974;24:1144-1151.

4 Kim HR, Kim YJ: Neurofibromatosis of the colon and rectum combined with other manifestations of von Recklinghausen's disease: case report. Dis Colon Rectum 1998;41:1187-1192. 
Chelimilla et al.: Incidental Finding of Isolated Colonic Neurofibroma

-5 Fuller CE, Williams GT: Gastrointestinal manifestations of type 1 neurofibromatosis. Histopathology 1991;19:1-11.

-6 Gogus S, Sarikayalar F, Akcoren Z, Yalnizoglu D, Hicsonmez A: Intestinal involvement and vasculopathy in von Recklinghausen's neurofibromatosis. Turk J Pediatr 1997;39:117-122.

7 Magro G, Piana M, Venti C, Lacagnina A, Ruggieri M: Solitary neurofibroma of the mesentery: report of a case and review of the literature. Pathol Res Pract 2000;196:713-718.

-8 Watanuki F, Ohwada S, Hosomura Y, Okamura S, Kawashima Y, Tanahashi Y, Nakamura S, Iino Y, Johshita T, Morishita Y: Small ileal neurofibroma causing intussusception in a non-neurofibromatosis patient. J Gastroenterol 1995;30:113-116.

-9 Frick EJ Jr, Lapos L, Vargas HD: Solitary neurofibroma of the anal canal: report of two cases. Dis Colon Rectum 2000;43:109-112.

10 Saitoh K, Nasu M, Kamiyama R, Hatakeyama S, Maruyama M, Tsuruta K, Takeshita K: Solitary neurofibroma of the esophagus. Acta Pathol Jpn 1985;35:527-531.

11 Sinha R, Paul R, Sen I, Sikdar B: A solitary huge neurofibroma of the soft palate. J Laryngol Otol 2002;116: 637-638.

12 Acebo E, Fernandez FA, Val-Bernal JF: Solitary neurofibroma of the gallbladder. A case report and review of the literature. Gen Diagn Pathol 1998;143:337-340.

13 Carbia S, Pagola J, Flaster N, Guida A, Jufe L, Gonzalez B, Caniparoli A: Isolated neurofibroma of the common bile duct. Medicina 1995;55:689-692.

14 Riddle ND, Gorden L, Rojiani MV, Hakam A, Rojiani AM: CD44 and p53 immunoexpression patterns in NF1 neoplasms - indicators of malignancy and infiltration. Int J Clin Exp Pathol 2010;3:515-521.

15 Keith AR: A case of neurofibromatosis of the rectal wall. Trans Am Proctol Soc 1937;38:68.

16 Woolf MS: Neurofibroma of the rectum. Calif West Med 1938;49:463.

17 Butler D, Hanna E: Neurogenic tumor of the rectum. Dis Colon Rectum 1959;2:291-294.

18 Suzuki H, Yamashita E: A case report of intestinal neurofibroma. Nihon Geka Hokan 1966;35:948-950.

19 Geboes K, De Wolf-Peeters C, Rutgeerts P, Vantrappen G, Desmet V: Submucosal tumors of the colon: experience with twenty-five cases. Dis Colon Rectum 1978;21:420-425.

20 Abramson IP, Orkin BD, Schwartz AM: Isolated colonic neurofibroma manifested by massive lower gastrointestinal bleeding and intussusception. South Med J 1997;90:952-954.

-21 Bononi M, De Cesare A, Stella MC, Fiori E, Galati G, Atella F, Angelini M, Cimitan A, Lemos A, Cangemi V: Isolated intestinal neurofibromatosis of colon. Single case report and review of the literature. Dig Liver Dis 2000;32:737-742.

22 Panteris V, Vassilakaki T, Vaitsis N, Elemenoglou I, Mylonakou I, Karamanolis DG: Solitary colonic neurofibroma in a patient with transient segmental colitis: case report. World J Gastroenterol 2005;11: 5573-5576.

-23 Carter JE, Laurini JA: Isolated intestinal neurofibromatous proliferations in the absence of associated systemic syndromes. World J Gastroenterol 2008;14:6569-6571.

24 Hindy P, Parvin R, Hanna K, Andrawes S, Gress F, Goodman A: An isolated neurofibromal polyp of the colon. Case Rep Gastroenterol 2012;6:58-62. 
Case Reports in
Gastroenterology

\begin{tabular}{l|l}
\hline \multicolumn{2}{l}{ Case Rep Gastroenterol 2013;7:369-375 } \\
\hline DOI: $10.1159 / 000355163$ & $\begin{array}{l}\text { C 2013 S. Karger AG, Basel } \\
\text { www.karger.com/crg }\end{array}$ \\
\hline
\end{tabular}

Chelimilla et al.: Incidental Finding of Isolated Colonic Neurofibroma

Table 1. Case reports of isolated gastrointestinal neurofibromas published in English literature

\begin{tabular}{lllllll}
\hline $\begin{array}{l}\text { Report } \\
\text { No. }\end{array}$ & Reference & $\begin{array}{l}\text { Year of } \\
\text { publication }\end{array}$ & $\begin{array}{l}\text { Age, } \\
\text { years }\end{array}$ & Gender & $\begin{array}{l}\text { Presentation/indication for } \\
\text { colonoscopy }\end{array}$ & $\begin{array}{l}\text { Location of } \\
\text { neurofibromas }\end{array}$ \\
\hline 1 & Keith [15] & 1937 & 50 & female & pain/diagnostic & rectum \\
\hline 2 & Woolf [16] & 1938 & 70 & male & $\begin{array}{l}\text { asymptomatic/screening } \\
\text { colonoscopy }\end{array}$ & rectum \\
\hline 3 & Butler and Hanna [17] & 1959 & 45 & female & $\begin{array}{l}\text { tenesmus and BRBPR/diagnostic } \\
\text { colonoscopy }\end{array}$ & rectum \\
\hline 4 & Suzuki and Yamashita [18] & 1966 & NA & NA & NA & intestine \\
\hline 5 & Geboes et al. [19] & 1978 & NA & NA & NA & rectum \\
\hline 6 & Abramson et al. [20] & 1997 & 53 & male & BRBPR/diagnostic colonoscopy & transverse colon \\
\hline 7 & Bononi et al. [21] & 2000 & 68 & female & $\begin{array}{l}\text { tenesmus and BRBPR/diagnostic } \\
\text { colonoscopy }\end{array}$ & $\begin{array}{l}\text { diffuse colonic } \\
\text { involvement }\end{array}$ \\
\hline 8 & Panteris et al. [22] & 2005 & 65 & female & $\begin{array}{l}\text { bloody diarrhea/diagnostic } \\
\text { colonoscopy }\end{array}$ & descending colon \\
\hline 9 & Carter and Laurini [23] & 2008 & 52 & female & $\begin{array}{l}\text { non-bloody diarrhea and abdominal } \\
\text { pain/diagnostic colonoscopy }\end{array}$ & $\begin{array}{l}\text { multiple - rectum and } \\
\text { transverse colon }\end{array}$ \\
\hline 10 & Hindy et al. [24] & 2012 & 59 & male & $\begin{array}{l}\text { asymptomatic/screening } \\
\text { colonoscopy }\end{array}$ & transverse colon \\
\hline
\end{tabular}

$\mathrm{BRBPR}=$ Bright red blood per rectum; NA = not available.

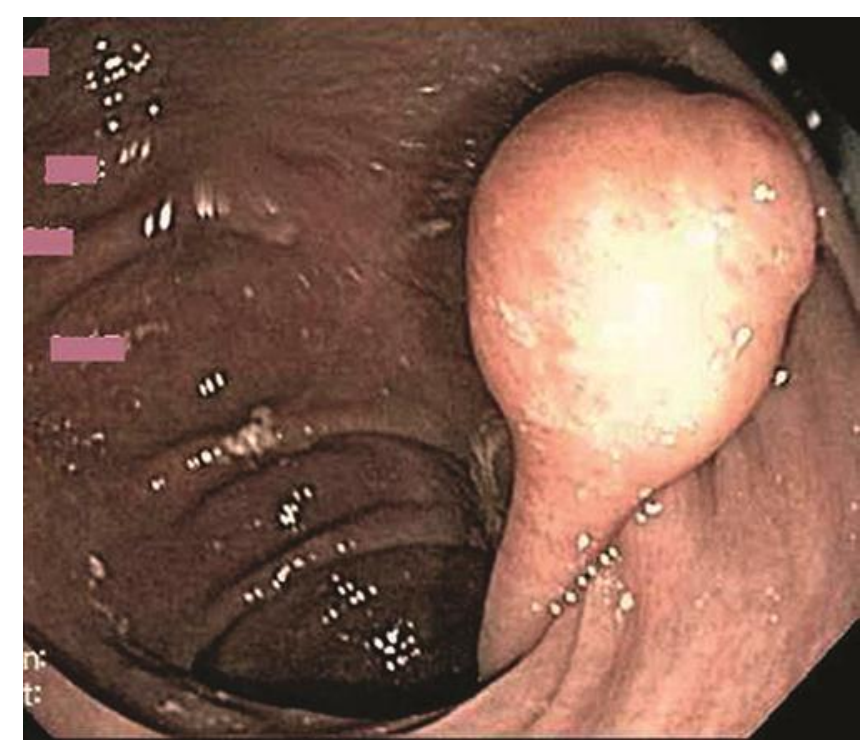

Fig. 1. Endoscopic view of the pedunculated polyp in the ascending colon. 


\begin{tabular}{|c|c|c|}
\hline \multirow{3}{*}{$\begin{array}{l}\text { Case Reports in } \\
\text { Gastroenterology }\end{array}$} & \multirow{2}{*}{\multicolumn{2}{|c|}{ Case Rep Gastroenterol 2013;7:369-375 }} \\
\hline & & \\
\hline & DOI: $10.1159 / 000355163$ & $\begin{array}{l}\text { (c) } 2013 \text { S. Karger AG, Base } \\
\text { www.karger.com/crg }\end{array}$ \\
\hline
\end{tabular}

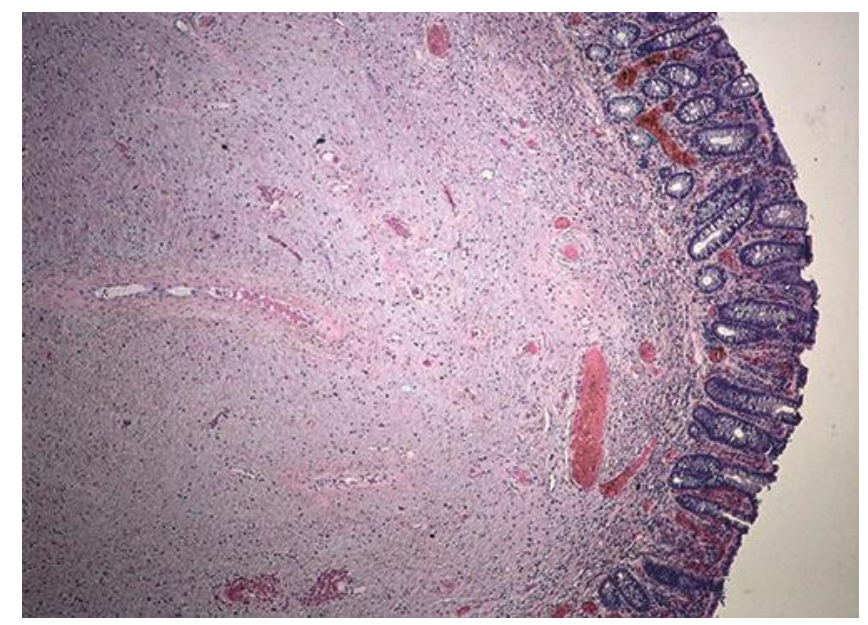

Fig. 2. Histological features of colonic neurofibroma. Low-power view of hematoxylin and eosin-stained colonic mucosa with bland spindle cell proliferation in the submucosa (original magnification $\times 10$ ).

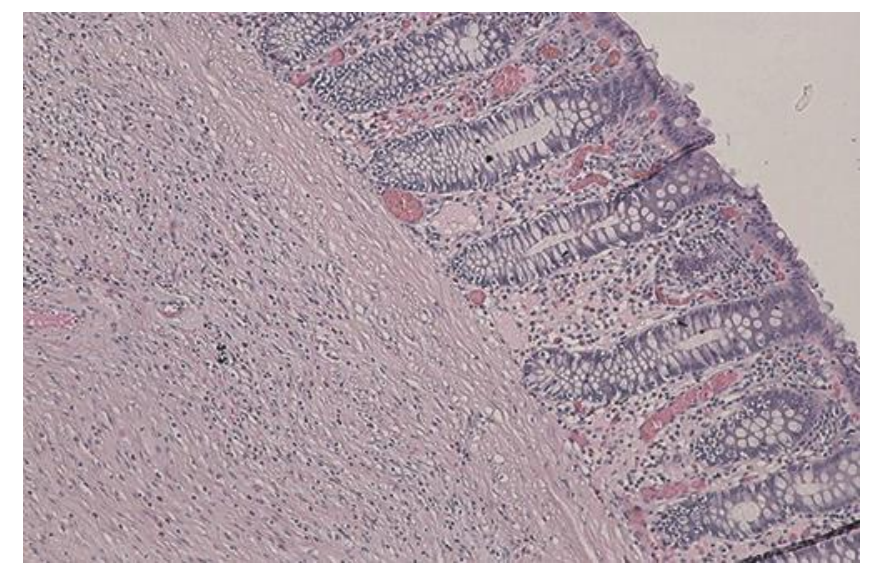

Fig. 3. Colonic neurofibroma in high-power view showing the spindle cells in the submucosa (original magnification $\times 40$ ). 


\begin{tabular}{|c|c|c|}
\hline \multirow{2}{*}{$\begin{array}{r}\text { Case Reports in } \\
\text { Gastroenterology }\end{array}$} & \multicolumn{2}{|c|}{ Case Rep Gastroenterol 2013;7:369-375 } \\
\hline & DOI: $10.1159 / 000355163$ & $\begin{array}{l}\text { (c) } 2013 \text { S. Karger AG, Basel } \\
\text { www.karger.com/crg }\end{array}$ \\
\hline
\end{tabular}

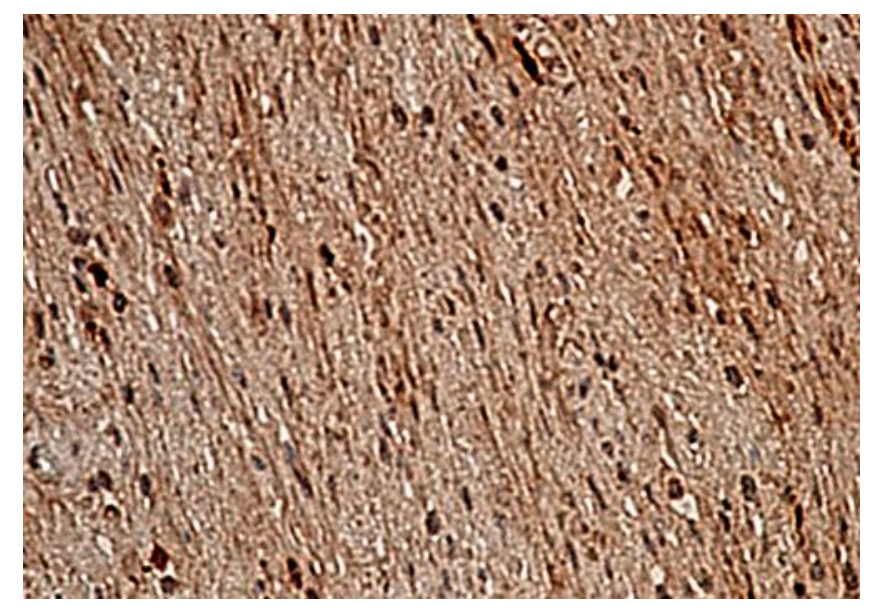

Fig. 4. Immunohistochemical features of colonic neurofibroma. The tumor cells are strongly positive for S100 protein immunostaining (original magnification $\times 40$ ). 